Review

\title{
Dirofilariasis in Russian Federation: a big problem with large distribution
}

\author{
Tatyana V. Moskvina ${ }^{1}$, Alexey V. Ermolenko ${ }^{2}$ \\ ${ }^{1}$ Far Eastern Federal University, Vladivostok, Russia \\ ${ }^{2}$ Federal Sciencific Center of Terrestrial Biodiversity of Eastern Asia, Far Eastern Branch Russian Academy of Sciences, Vladivostok, Russia
}

Received 13 June 2017, Revised 19 October 2017, Accepted 16 November 2017

(C) 2017, Moskvina T.V., Ermolenko A.V.

C 2017, Russian Open Medical Journal

\begin{abstract}
Dirofilariasis caused by Dirofilaria spp. is an important vector-borne and largely zoonotic disease. In Russia, dirofilariasis is caused by two agents $D$. immitis and $D$. repens. The present article provides detailed analyses of human and canine dirofilariasis methods of diagnosis, treatment, and prevention of the disease, with particular reference to the control programmes. Information has been summarised from literature in different languages that are not readily accessible to the international scientific community.

Human dirofilariasis was first registered in Russia in 1915, and recent reports showed that the total number of infected humans increases on average by 1.8 times every three years. Human dirofilariasis was registered in 42 federal subjects. Totally 1162 cases of subcutaneous dirofilariasis were registered in the Russian Federation between 1915-2013, the most frequently type of subcutanious dirofilariasis was ocular dirofilariasis (more than $50 \%$ cases). Seven cases of pulmonary dirofilarisis were registered in Russia. The treatment of human dirofilariasis includes surgical removal of worms only; in result preventive measure have major importance for reducing risk of Dirofilaria infection. Control programmes have been implemented by the government at all administrative levels including diagnosis and treatment of patients, identification, isolation, and treatment of infected dogs, monthly chemoprophylactic of dogs during spring-summer periods, and regular vector control.
\end{abstract}

Keywords: dirofilariasis, heartworm diseases, human, Russia

Cite as Moskvina TV, Ermolenko AV. Dirofilariasis in Russian Federation: a big problem with large distribution. Russian Open Medical Journal $2018 ;$ 7: e0102.

Correspondence to Tatyana V. Moskvina. E-mail: rabchan1992@gmail.com. Tel.: +79020572964.

\section{Introduction}

Dirofilariasis is an important vector-borne and globally distributed zoonotic disease [1-3] and it is a single vector-born disease caused by a nematode in the Russian Federation [4]. The disease is caused by roundworms in the genus Dirofilaria (Nematoda: Onchocercidae) and is naturally transmitted by mosquitoes. The Dirofilaria life cycle includes an invertebrate host and a vertebrate definitive host $[5,6]$. Six of 40 species from the Dirofilaria genus are responsible for affecting humans [7]. Two main filarid species, $D$. repens and $D$. immitis, were found in the Russian Federation, and these species also have the high prevalence, veterinary and medical importance worldwide $[1,8$, 9].

The $D$. repens and $D$. immitis life cycles include mosquito vectors from the Culicidae and final hosts of different domestic and wild carnivorous animals [10, 11]. Both Dirofilaria species demonstrate low host specificity and can affect many mammals. Humans are accidental hosts for Dirofilaria, thus adult nematodes do not reach maturity in their heart or skin [1, 12-14]. D. repens and $D$. immitis follows that of other Dirofilaria species in that infected mosquitoes, introduce third-stage larvae (L3) into the vertebrate host during a blood meal. The L3 larvae molt first into fourth-stage larvae (L4) and then adults within the vertebrate host
$[15,16]$. Canine dirofilariasis, caused by $D$. repens, induces such clinical signs as a pruritus, dermal swellings, subcutaneous nodules, alopecia and erythema [17-20]. Canine infestation caused by $D$. immitis is frequently asymptomatic, depending on worm burden and duration of infection [21, 22]. Heavy infestation with a high worm burden can produce clinicopathologic manifestations, including pulmonary endarteritis, hypertension, thromboembolism and pneumonitis [23-26].

There are three types of dirofilariasis distinguished in humans, depending on clinical signs: subcutaneous dirofilariasis (SD), ocular dirofilariasis (OD) and pulmonary dirofilariasis (PD) [27-29]. SD usually manifests as a single subcutaneous nodule, which is caused by macrofilaria trapped by the immune system [27]. Subcutaneous migration of the worm may result in local swellings with changing localisation (creeping eruption) [31]. In addition, rare cases of organ manifestation have been reported, affecting the scrotum, male genitals, female breast, lymphatic glands and peritoneum [2, 32-38]. OD is a variation of subcutaneous dirofilariasis with parasite localisation in the eye area [30]. Eye involvement may be periocular, sub-conjunctival, subtenons, or intraocular [39-42]. PD caused by $D$. immitis is a less frequent type of dirofilariasis. Clinical signs include a single pulmonary nodule forming around immature macrofilaria $[43,44]$. In rare cases, multiple lesions have also been described $[45,46]$. 
Table 1 Dirofilaria prevalence in mosquitoes

\begin{tabular}{|c|c|c|c|}
\hline Region & Mosquito vector & Prevalence & Refs \\
\hline Moscow Federal District $(n=1554)$ & Total prevalence $-2.4 \%$ & D. repens & [52] \\
\hline Astrachan $(n=334)$ & Aedes $-3.3 \%$, Anopeles $-1.9 \%$, Culex $-5.8 \%$ & Dirofilaria s & [55] \\
\hline Tula $(n=2277)$ & $\begin{array}{l}\text { Cx. pipiens }-0.01-0.08 \%, \text { Ae. caspius }-0.02-0.08 \%, \text { Ae. dorsalis }-0.02-0.08 \% \text {, } \\
\text { An. messeae }-0.01-0.04 \%\end{array}$ & D. repens & [54] \\
\hline Rostov on Don $(n=482)$ & Aedes -0\%, Anopeles - $0.86 \%$, Culex $-1.37 \%$ & Dirofilaria si & {$[58]$} \\
\hline Chabarovsk $(n=1284)$ & Aedes $-3.7 \%$, Anopeles - $10 \%$, Culex $-4.1 \%$ & Dirofilaria s & [56] \\
\hline Anapa $(n=550)$ & Aedes $-0.44 \%$, Culex $-0.46 \%$ & Dirofilaria s & [51] \\
\hline \multirow[t]{2}{*}{ European Part of Russia $(n=45714)$} & $\begin{array}{l}\text { Cx. pipiens }-0.01-0.08 \%, \text { Ae. caspius }-0.02-0.08 \% \text {, Ae. aegypti }-0.01-0.06 \% \text {, } \\
\text { An. maculipennis }-0.01-0.04 \%\end{array}$ & D. repens & {$\left[\left.\mathrm{url}\right|^{*}\right]$} \\
\hline & $\begin{array}{l}\text { Cx. pipiens }-0.01-0.08 \%, \text { Cx. modestus }-0.01-0.06 \%, \text { Ae. caspius }-0.01-0.08 \% \text {, } \\
\text { An. maculipennis }-0.01-0.06 \%\end{array}$ & D. immitis & {$[51]$} \\
\hline
\end{tabular}

$\mathrm{n}$-total number of mosquitoes investigated. Cx., Culex; Ae., Aedes; An., Anopeles. [url*], http://fguz-volgograd.ru/component/content/article/1197.

Table 2. Mosquitoes species that are involved or potentially involved in the transmission of Dirofilaria spp.

\begin{tabular}{ll}
\hline Species & Part of Russia [Refs] \\
\hline Aedes aegipty & European, Asian [51] \\
Aedes albopictus & European, Asian [52] \\
Aedes caspius & European, Asian [51, 53] \\
Aedes dorsalis & European, Asian [51, 53] \\
Aedes koreicus & European, Asian [50] \\
Anopeles maculipennis & European [52] \\
Anopeles messeae & European, Asian [54] \\
Culex pipiens & European, Asian [51, 54] \\
\hline
\end{tabular}

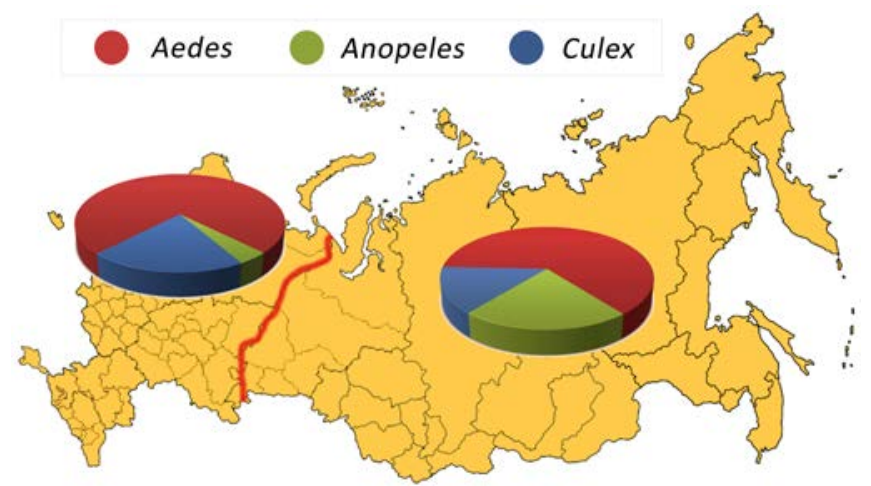

Figure 1. Distributions of mosquitoes from the Culicidae family in the Asian (left) and European (right) parts of Russia (the data shown from references [48-50]).

Mosquitoes from the Culicidae family serve as vectors to transmit Dirofilaria spp. The L1 stage larvae are ingested by feeding mosquitoes, then larvae moult twice over 8-17 days, and this time highly depends on temperature. For L3 development stage larvae, the average temperate is at least $20^{\circ} \mathrm{C}$ for two weeks. It has been experimentally demonstrated that the development of infectious $L 3$ larvae requires $8-10$ days at $28-30^{\circ} \mathrm{C}, 11-12$ days at $24^{\circ} \mathrm{C}$, and $16-20$ days at $22^{\circ} \mathrm{C}$. Below $14^{\circ} \mathrm{C}$, development arrests, although it can be restarted when the temperature increases above this threshold. Consequently, the climate and associated changes can determine the presence and dynamics of transmission of dirofilariasis in temperate regions. If the temperature is inadequate, development of L3 stage larvae does not occur $[1,46]$.

This review summarises the current status of dirofilariasis in Russia, with particular focus on the impact of control and prevention of infestation among domestic dogs and cats, and humans.

References for this review were collected by searching Elibrary (elibrary.ru), Google Scholar, PubMed, and the ISI Web of Knowledge. Search terms used included "dirofilariasis," "Dirofilaria repens", "Dirofilaria immitis", "canine dirofilariasis", "feline dirofilariasis", "dirofilariasis Russia". Relevant articles or book chapters in English and Russian were also consulted. Epidemiological data were obtained from the articles cited, and reports released by the Ministry of Health of the People's Russian Federation. The search of these databases was completed in 2016, when this review was prepared. During revision of the manuscript, additional citations brought to our attention were added. There were no restriction on the type of study design. Following the initial screening, the references of all eligible studies were examined to identify any other potentially relevant articles. Because this is not a systematic review evaluations of methodological quality were not used to exclude papers from the study.

The review was divided in five parts: in part 1 publishing studies about mosquitoes transmitted Dirofilaria in Russia were included; in part 2 publishing epidemiologic studies that reporting Dirofilaria prevalence, symptoms of dirofilariasis in domestic dogs were included. In part 3 all included reports were focused of human didofilariasis in Russia; in part 4 studies about diagnostic methods and treatment of dirofilariasis both in humans and animals were included. In part 5 studies summarised controls and prevention procedures of dirofilariasis provided in Russia were included.

\section{Vector scpecies in Russia}

The Culicidae family is a large group including more than 3000 species globally distributed [47]. Nevertheless 31 mosquito species from the Culicidae family, including the genera Aedes meigen, Culex linne, Anopeles meigen, Culiseta feit and Ochlerotatus lyncharribalzaga, transmit Dirofilaria spp [1]. In the Russian Federation, Culicidae fauna includes 94 species with diversity in both the European and Asian parts of Russia (Figure 1) [48-50]. However, the importance of different species in Dirofilaria spp. transmission is underestimated. Sporadic reports indicate different prevalence rates of Dirofilaria spp. in mosquitoes from three genera: Aedes, Culex and Anopeles, and prevalence rates of Dirofilaria spp. in mosquitoes are significantly different in different regions (Table 1). However, eight species of mosquito from the Culicidae family are most frequently involved in the transmission of Dirofilaria spp. In Table 2, we present the list of species found in Russia, which have the capacity to transmit Dirofilaria based on data published in the Russian Federation [50-54]. 
Table 3. Dirofilaria spp. prevalence in domestic dogs

\begin{tabular}{|c|c|c|c|}
\hline Region (n) & $\begin{array}{l}\text { Dirofilaria species and } \\
\text { prevalence (\%) }\end{array}$ & Age group & Refs \\
\hline Novgorod region $(n=108)$ & Dirofilaria spp. $-28.7 \%$ & - & [61] \\
\hline Altay region $(n=3535)$ & Dirofilaria spp. $-11.7 \%$ & - & {$[62]$} \\
\hline $\begin{array}{l}\text { Moscow Federal District } \\
(n=3371)\end{array}$ & $\begin{array}{l}\text { D.repens }-0.65 \% \text {, } \\
\text { D.immitis }-3.4 \%\end{array}$ & $\begin{array}{l}2-3 \text { years old }-11 \%, 4-6 \text { years old }-14.0 \% \text {, } \\
7-9 \text { years old }-78.3 \% \text {, older than } 9 \text { years }-2.4 \%\end{array}$ & [63] \\
\hline Kirov region $(n=233)$ & $21.8 \%$ & $\begin{array}{l}8 \text { months old }-2.4 \%, 2 \text { years old }-4.9 \%, 3-6 \text { years } \\
\text { old }-56.1 \% \text {, older than } 7 \text { years }-34.1 \%\end{array}$ & {$[64]$} \\
\hline Voronezh region $(n=424)$ & $\begin{array}{l}\text { D. } \text { immitis }-36.5 \% \text {, } \\
\text { D. repens }-63.5 \%\end{array}$ & - & {$[65]$} \\
\hline Barnaul $(n=121)$ & $\begin{array}{l}\text { Dirofilaria spp. }-33.3 \% \text {, } \\
\text { D. immitis }-10.5 \% \text {, } \\
\text { D. repens }-3.9 \%\end{array}$ & $\begin{array}{l}1-3 \text { years old }-15.4 \%, 4-6 \text { years old }-42.3 \%, 7-9 \\
\text { years old }-30.8 \% \text {, older than } 10 \text { years }-11 . \%\end{array}$ & {$[66]$} \\
\hline Krasnodar $(n=3366)$ & $\begin{array}{l}\text { D. } i m \text { mitis }-28 \% \text {, } \\
\text { D. repens }-0.12 \%\end{array}$ & $\begin{array}{l}1-3 \text { years old }-15.6-29.9 \%, 4-8 \text { years old }-26,9- \\
39.2 \%\end{array}$ & [67] \\
\hline Astrakhan region $(n=5729)$ & Dirofilaria spp. $-2.9 \%$ & $x^{2}-1$ & {$[56]$} \\
\hline Anapa $(n=38)$ & $\begin{array}{l}\text { D. repens }-15.7 \% \text {, } \\
\text { D. immitis }-5.3 \% \text {, } \\
\text { D. repens + D. immitis } 5.3 \%\end{array}$ & $\begin{array}{ll}2 \text { years old }-10 \%, 5-7 \text { years old }-80 \%, 8 \text { years old }- & \text { males }-60.0 \% \\
10 \% & \text { females }-40.0 \%\end{array}$ & [57] \\
\hline Chabarovsk $(n=41)$ & Dirofilaria spp. $-29.2 \%$ & $\begin{array}{l}1-3 \text { years old }-29.2 \%, 4-5 \text { years old }-16.7 \% \text {, } \\
6-8 \text { years old }-66.7 \%\end{array}$ & {$[68]$} \\
\hline Yakutsk $\left(n=14^{*}, n=33\right)$ & $\begin{array}{l}\text { Dirofilaria spp. }-51.5 \% \text {, } \\
\text { D. repens }-21.4 \% \text {, } \\
\text { D. immitis }-47.8 \%\end{array}$ & $\begin{array}{l}1-3 \text { years old }-10.0 \%, 4-8 \text { years old }-33.3 \% \text {, } \\
\text { older than } 9 \text { years }-3.33 \%\end{array}$ & [69] \\
\hline Penza $(n=1269)$ & Dirofilaria spp. $-9.1 \%$ & - & [url*] \\
\hline Perm $(n=125)$ & $\begin{array}{l}\text { D. } \mathrm{immitis}+\mathrm{D} \text {. repens - } \\
0.8 \%, \mathrm{D} \text {. repens }-3.2 \%\end{array}$ & - & {$[70]$} \\
\hline Kalmyk Republic $(n=180)$ & D. repens-24.4\% & $\begin{array}{ll}-- \\
-\end{array}$ & {$[71]$} \\
\hline Kostromskoi Region $(n=234)$ & Dirofilaria spp. $-33.0 \%$ & $\begin{array}{l}2-3 \text { years old }-57.0 \%, 4 \text { years old }-14.0 \% \text {, } \\
7-8 \text { years old }-29.0 \%\end{array}$ & [72] \\
\hline
\end{tabular}

$\mathrm{n}$, total number of investigated animals. [url*], http://58.rospotrebnadzor.ru/rss all/-/asset_publisher/Kq6J/content/id/290168. ${ }^{*}$ Postmortern examination.

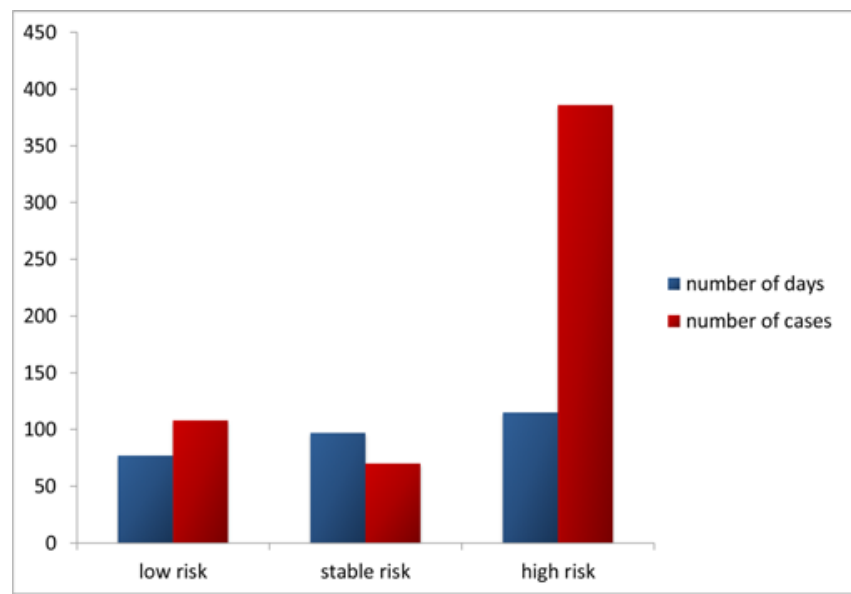

Figure 2. The number of days (blue) and the number of cases (red) for each zone of transmission $\square$ low rik, stable risk, and high risk of human dirofilariasis (The data summarized from reference [4]).

\section{Geographical distribution of dirofilariasis in Russia}

The area of spread of Dirofilaria spp. in Russia depends on the source of infection and the area of spreading of vector-mosquitoes Anopeles, Aedes and Culex. Dirofilaria spp. were found in 42 federal subjects of the Russian Federation, where mean temperature in July is at least $17^{\circ} \mathrm{C}$ in the north zone and at least $24^{\circ} \mathrm{C}$ in the south zone $[4,60]$. The number of days with temperature higher than $15^{\circ} \mathrm{C}$ was $60-70$ per year in the north and more than 120 days in the south. Three zones of Dirofilaria spp. transmission are distinguished in Russia. This classification is based on geographic and climatic conditions, and determines the development of vectors (Figure 2). The zone of stable risk of transmission includes 11 subjects in the European part of Russia (41-56 N), the south border of which is located on the foothills of the Kaucazian Mountains. The high risk of Dirofilaria spp. transmission depends on high temperatures in July $\left(20-24^{\circ} \mathrm{C}\right)$, and temperatures higher than $15^{\circ} \mathrm{C}$ for 110 days; the transmission season is approximately 3-5 months. This zone includes five Federal Subjects: Rostov Federal District, Volgograd Federal District, Astrakhan Federal District, Saratov Federal District and Krasnodar region. The mean risk of transmission zone (51-55 N) includes 18 federal subjects, including the territories of Tatarstan Republic, Chelyabinsk and Kurgan Federal Districts (56 N), Far Eastern Federal District (42-52 N), Chabarovsky region, Amursky District, and European Jewish Autonomic District, Prymorsky Region. The average temperature in July is $19-21^{\circ} \mathrm{C}$ and the temperate is higher than $15^{\circ} \mathrm{C}$ for $90-105$ days. The low risk of transmission zone (54-58 N) includes 12 federal subjects. The maximum temperature in July is $17.5-19^{\circ} \mathrm{C}$ and the temperature is higher than $15^{\circ} \mathrm{C}$ for $60-90$ days $[4,55]$.

\section{Canine dirofilariasis}

Both species, $D$. immitis and $D$. repens, were found in dogs in Russia. The first cases of canine dirofilariasis caused by $D$. repens were registered in Sovet Union territories in the Kharkov region (Ukraine), near the border of the Rostov region, in the Bukhara Region and in the Rostov region. D. immitis was firstly reported in dogs from the territory of the Azerbaijan Republic. Later, this species were also identified in the Turkmenistan Republic, in the Far East Ussuri region and in Abkhazia [61, 62]. Recently, dirofilariasis was registered in dogs from 17 regions [56, 57, 61- 
73]. The minimum prevalence was $0.12 \%$ and the maximum prevalence was $63.5 \%$ (Table 3 ). There was no common tendency for differences in the prevalence for sex; the prevalence in males and females fluctuated in different regions. In the Ulyanovsk region, male and female dogs had equal prevalence rates; in Barnaul and Anapa, female dogs were more frequently affected than male dogs (Table 3). Conversely, the Dirofilaria spp. prevalence was higher in males than in females in the Chabarovsky region [68]. Dirofilariasis was found in dogs of different age groups. However, cases of Dirofilaria spp. infestation were not found in puppies younger than six months old (Table 3). High infection rates were found in dogs between four and six years old and the lowest prevalence was found in one-year-old dogs. Dogs older than six years had the lower Dirofilaria spp.prevalence than dogs between four and six years old (Table 3). Dirofilariasis in dogs can be asymptomatic, and in some cases, Dirofilaria spp. infection causes disorders with different clinical symptoms, depending on parasite species and intensity of infection. Cardiopulmonary dirofilariasis caused by $D$. immitis is frequently fatal for dogs [73, 74]. Totally three clinical forms of dirofilariasis are distinguished:

i) Mild (asymptomatic). Dogs with this form of disease do not have clinical signs. Dirofilariasis was determined by blood sample analyses. However, laboratory tests frequently show eosinophilia, proteinuria, and increased lactate dehydrogenase rates.

ii) Moderate. Cardiopulmonary disease withchronic renal pathology. All animals tire easily; the lack of breath and cough frequently appear. Radiography shows expansion of pulmonary arteries. Ultrasonography of the heart and abdominal organs shows an increase in the right ventricle and renal sucker, and prostate cyst is also appeared. Echocardiography shows arrhythmia.

iii) Caval syndrom. Cardiopulmonary disease with thromboembolic, chronic renal and hepatic pathology. Animals in this group have fatigue, cough, and shortness of breath, weight loss, jaundice, and ascites. Radiography shows an increase in heart borders and expansion of pulmonary arteries. Heart ultrasound revealed an increase in right ventricular infarction and thinning of fluid in the pericardium. Ultrasound of the abdominal cavity shows increased size liver and hepatic veins, enlargement of the spleen, and expansion of the renal pelvis, prostate cysts and ascites. Violation of the heart and sinus arrhythmia appears in echocardiography. This form is found frequently among affected dogs.

$D$. repens causes subcutaneous dirofilariasis in dogs and less pathogenicity than $D$. immitis. Canine subcutaneous dirofilariasis is frequently asymptomatic. Clinical manifestations are classified into two clinical forms: multifocal nodular dermatitis and papular dermatitis. Both clinical forms frequently present with leukocytosis, proteinuria and increased alkaline phosphatase. Both clinical forms have equal frequency among affected dogs [73-75].

\section{Human dirofilarisis}

The first case of human dirofilariasis was reported in 1915 by A.P. Vladychenskiy, who found filaria in a nodule between the orbital wall and eyeball [101]. Regular researches were produced after 1930, when columnist of Soviet Helminthological School, K.I. Skriabin, completely described ocular dirofilariasis [76].
Dirofilariasis was first included in Russian Sanitary Regulations and Standards (No.3.2.1333-03 "Profilactic of parasitic diseases in Russian Federation") in 2003. Now dirofilariasis was registered in 42 federal subjects. In total, 1093 cases of human dirofilariasis were registered in 1915-2012 [59]. Early reports were published mainly in southern regions of Russia: in Chabarovsky region, the first case of human dirofilariasis was registered in 1929 [76]; in Astrahan District in 1951 [78]; in Altay Region in 1989 [79] and in Ryazansky District and Irkutsky District in 1997 (data from: http://cgie.62.rospotrebnadzor.ru/info/91828). The latest reports published from south regions [80-84] were Penzensky District (2000); Ivanovsky district, Permsky District (2004); Smolensky District (2007); Kirovsky District (2008).

A stable tendency for increasing numbers of cases of human dirofilariasis is observed in Russian Federation. During 1996-2001, a total of 152 cases of Dirofilaria infestations were registered, whereas 227 cases were registered between 2011-2012 [85-87]. The total number of infected humans increases in average by 1.8 times every three years [87]. However, the real number of affected people is underestimated, due to low quality of diagnostic procedures, difficulty of filaria extraction, and incomplete data of Dirofilaria infestations. In 2013, a new form of dirofilariasis, found in Rosstat, was reported [59]. From 1915, the date of the first Russian reported case of dirofilariasis, to 2014, most reported cases were found in a restricted number of southwestern administrative units [59]. Nevertheless, data analysis revealed three regions with high levels of dirofilariasis. The Rostovsky region had the highest Dirofilaria infestation rates -242 cases [8, $58,59,88,89]$, Nizhegorodsky region had the second highest -129 cases [58], and Volgogradsky district had the third highest - 93 cases $[59,90]$. Warm climate conditions and high infestation rates of Dirofilaria in mosquitoes and dogs in Rostovsky and Volgogradsky regions contribute to high prevalence rates of human dirofilariasis. High levels of Dirofilaria infestation were found in people from the Nizhegorodsky region associated with kennel dogs, which delivered infected mosquitoes from Chechensky Republic [59]. There is lack information about gender and age distribution of people infected Dirofilaria spp. in Russia. Data reported by Ministry of Health show, that in 2012 years 143 cases of dirofilariasis were registered in people between up 1 year to 87 years old. Dirofilariasis was registered in $76 \%$ woman (109 cases) and $24 \%$ man (34 cases) (data from: http://rospotrebnadzor.ru/documents/details.php?ELEMENT ID=

651). The most frequently registered infection was subcutaneous dirofilariasis. In total, 1162 cases of SD were registered in the Russian Federation between 1915-2013 [91] and 782 described cases were caused by $D$. repens [91]. Map of Dirofilaria spreading in Russian Federation were presented by Ermakova et al. (2014) [8]. Dirofilaria spp. were frequency localised in the ocular area (more than $50 \%$ cases) $[8,79,81,83,84,88,89-102]$ follow head and face $[8,81,88-92,96]$, upper limbs $[8,88,89,92,96-100]$, stomach [8, 88, 89], genitals [8, 83, 84, 88, 89, 91, 106, 107], breast and knees $[8,67,88,89,91,92,104,108]$ (Figure 3).

\section{Rare cases of human dirofilarisis}

Three unusual types of human dirofilariasis were registered in the Russian Federation [108-110]. In one case Dirofilaria spp. was extracted from intracerebral haematoma via autopsy from a 41year-old patient, who had stenosis and occlusion of major carotid vessels, venous sinus and bone destruction of the skull base [109]. 
Typical signs of subcutaneous dirofilariasis (nodules, lymphatic and optical fields, creeping eruption) were not present. Other case of subcutaneous dirofilariasis was described in a 49-year-old female, with dirofilariasis of the tendinous sheath of the extensor pollicis longus [110]. The patient was admitted to hospital with a diagnosis of dorsal hand ganglion cyst, and correct diagnosis was made after worm extraction. The first case of microflaria detection in a patient in the Saratov region, who had clinical manifestations of a $D$. repens infestation, was described in the Moskow region by Supriaga et al. [111].

Table 4. Pulmonary dirofilariasis in Russia

\begin{tabular}{|c|c|c|}
\hline Patient & Dirofilaria species & Clinical signs \\
\hline Male, 40 years old & D. repens & $\begin{array}{l}\text { Pain in the chest, lack of } \\
\text { breath, cough }\end{array}$ \\
\hline Male, 34 years old & Dirofilaria sp. & $\begin{array}{l}\text { Pain in the chest, body } \\
\text { temperature } 39^{\circ} \mathrm{C}\end{array}$ \\
\hline Female, 60 years old & D. repens & $\begin{array}{l}\text { Pain in the chest, cough, } \\
\text { body temperature } 37.2- \\
37.6^{\circ} \mathrm{C}\end{array}$ \\
\hline Female, 75 years old & D. repens & No clinical signs \\
\hline Male, 47 years old & D. repens & $\begin{array}{l}\text { Pain in the chest, cough, } \\
\text { body temperature } 39^{\circ} \mathrm{C}\end{array}$ \\
\hline
\end{tabular}

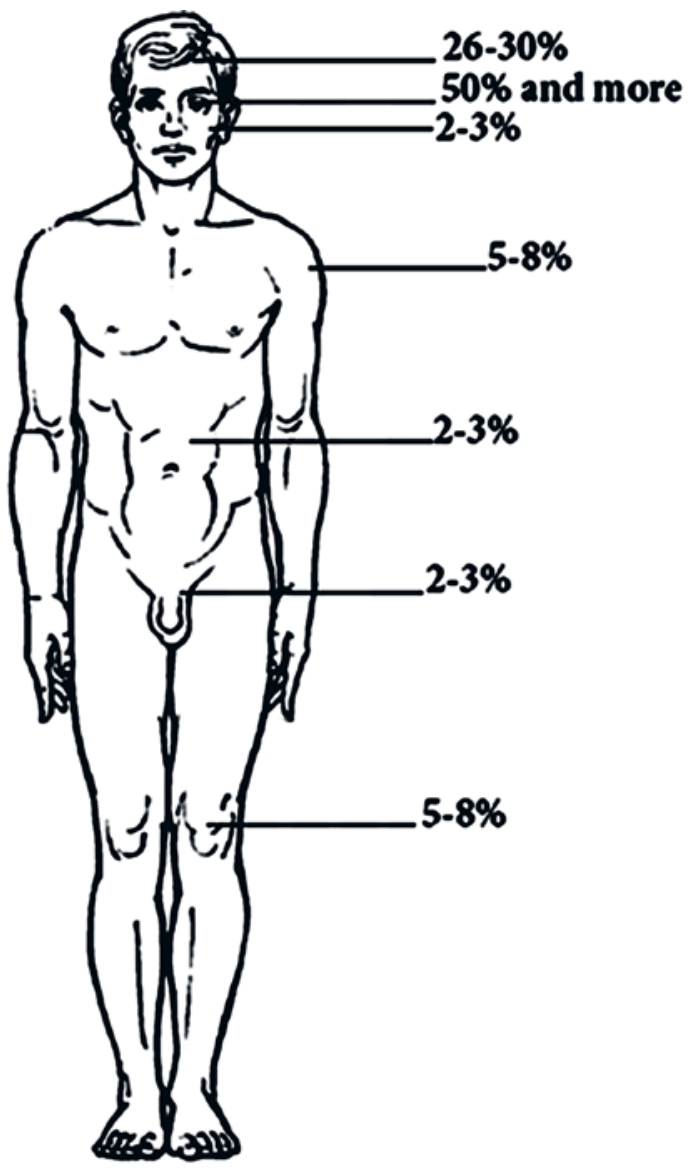

Figure 3. Areas of Dirofilaria spp. localisation

\section{Human pulmonary dirofilarisis}

In total, seven cases of pulmonary dirofilariasis were registered in Russia. Six cases were described in the Ivanovo region and one case was described in Moscow. Single pleural nodules were found in five patients [112, 113] (Table 4); two cases were autochthonous pulmonary dirofilariasis with the development of recurrent exudative pleurisy and "nummular" pulmonary nodules $[114,115]$.

\section{Dirofilariasis diagnostic procedures}

\section{Diagnostic of canine dirofilariasis}

Canine dirofilariasis diagnostic in Russia is conducted by standard procedures, including the blood sample analysis, immunoassay tests and polymerase chain reaction (PCR) analysis, which are also complement by ultrasonography, radiography and clinical sign analysis. The blood test analysis include standard procedures: methods of direct microscopy of the fat blood drop, Knott's method, Wyllie's method, which are used worldwide [1]. Due to the fact that the blood test analysis and ultrasonography and radiography used both for humans and animals we don't distinguish this chapter in two parts.

Some modified blood samples analyses for Dirofilaria diagnostic use in Russia. For example, Supryaga \& Andreenkov [116] proposed a dirofilariasis diagnostic method for medical practice for patients with a low density of microfilariae in the blood. The authors proposed a modification whereby microfilariae are detected using stained ultrafilters, which are domestically produced. In this method, haemolysed blood passes through ultrafilters under vacuum.

Another method was proposed by Kolesova et al [69]. Blood samples are left at low temperature $\left(4-15^{\circ} \mathrm{C}\right)$ for $20-24$ hours with $\mathrm{K}_{2}$-EDTA (Editor's comment: EDTA, Ethylenediaminetetraacetic acid) added. Blood is divided into plasma and sediment, which forms a funnel-like cavity containing microfilaria on the boundary between plasma and sediment. Blood samples (15-20 ml) are taken from the bottom of the funnel and mixed with Lughole $1 \%$ solution, followed by microscopy investigation.

V.B. Yastreb suggested modified Knott's technique [117]. Blood samples (2-3 ml) were mixed with $5 \%$ sodium citrate (1:20). Then, $1 \mathrm{ml}$ samples of canine and feline blood aliquots were placed in a 10-ml centrifuge tube with $9 \mathrm{ml}$ distilled water added. The tubes were left at room temperature for at least $5 \mathrm{~min}$ for erythrocyte haemolysis, with further cenrifugation at $2000 \mathrm{rpm}$ for $5 \mathrm{~min}$. The supernatant was then discarded, and sediment $(0.5 \mathrm{ml})$ retrieved in the microscopic fields was identified on the basis of differential morphometric (i.e. length and width) and morphological (i.e. head and tails) features of canine and feline filariae under light microscopy at 200x, 400x and 1000x magnifications. This method is as effective as the classic Knott method and has a number of advantages: 1) larvae in the sediment are alive and microfilariae viability can be studied according to the conditions and timing of blood storage, which is especially important in the preparation of secretory antigens of the parasite; 2) microfilaria drug efficacy can be estimated in in vitro and in vivo conditions. In addition, modified quality tests were suggested by Arkhipova \& Arkhipov [118] using a mixing pipette and a Fucs-Rozanthal counting chamber. Blood taken from the ear vein was placed into the mixing pipette up to mark I, and filled to mark II with solution containing glacial acetic acid, 
fuchsine solution, and distilled water (ratio of 3:4:93). The coverslip glass was ground in a clean and dry Fuchs-Rosenthal chamber until the so-called Newton's rings were visible. The mixing pipette with the blood and solution was shaken and a blood drop (not the first) was applied to the middle of the chamber plate and checked using a microscope. The numbers of microfilariae in all squares were counted. Immunoassay tests are the "gold standard" for diagnosis of Dirofilaria infection both in pets and humans. Diagnosis can also be performed using Elisa kits. However, high cost and low accessibility of this kit has limited its large-scale use. In addition, PCR tests were conducted according to the standard procedure [89, 119].

Due to limitations, it is necessary to use home-produced immunoassay tests. Beskrovnaya et al. $[120,121]$ suggested a procedure for somatic Dirofilaria antigen extraction. Pure somatic antigen was extracted from immature female $D$. repens worms. Removed worms were homogenised mechanically followed by ultrasound sonication and then extraction of proteins in $0.25 \mathrm{M}$ aqueous sucrose solution. Samples were subject to further purification from lipids in acetone solution by centrifugation, and then the supernatant is discarded. The sediment was dried under vacuum and diluted in potassium phosphate buffer $(\mathrm{pH}$ 6.4) with further purification by centrifugation. Derived antigen was used at a concentration of $40 \mu \mathrm{g} / \mathrm{ml}$ in a volume of $100 \mu \mathrm{l}$ per well. The sensitivity and specificity values of indirect immunofluorescentantibody test (IFA) were $84.0 \%$ and $86.4 \%$, respectively [120, 121].

However, immature Dirofilaria female specimens are not frequently found in clinical practice, thus another immunoassay analysis was conducted using somatic antigens from Setaria labiatopapillosa and Setaria equina [122]. Protein spectra for both species contained identical antigens for Dirofilaria antigens that are used in the diagnosis of Dirofilaria spp. infections. Both methods mentioned above used for Dirofilaria detection in dogs. However, immunoassay tests can produce false-negative results, especially for cats [1]. Molecular biotechnology has also been evaluated for diagnosing dirofilariasis in Russia. For example, MALDI-TOF MS (Editor's comment: MALDI is the abbreviation for "Matrix Assisted Laser Desorption/Ionization"; TOF MS is the abbreviation for "Time of Flight Mass Spectrometry") has been used for the identification of $D$. repens and $D$. immitis in dogs [123]. The analytical procedure does not require large material or labour expenditures, nor does it require experience of taxonomic studies in parasitology. The main obstacle for application of MALDI-TOF MS is the cost of the apparatus, but this expense is covered from the economical point of view. However, this method is rarely used in Russia, due to the high cost of the apparatus. It is therefore necessary to use combined diagnostic methods for Dirofilaria detection.

\section{Human dirofilariasis diagnostic}

Opposite to canine dirofilariasis diagnostic, identification of Dirofilaria worms in humans is usually spontaneous and it is often performed by patients, appeared worm in subcutaneous area in body or in the eye. Dirofilaria worms are also extracted using surgery of subcutaneous nodules. How it was mentioned above, humans are accidental hosts for Dirofilaria; so direct blood samples analyses for microfilaria are not useful for diagnostic of human dirofilariasis [1]. Human pulmonary dirofilariasis is a great medical importance problem, due to the absence of specific symptoms. Patients can be asymptomatic or have signs of respiratory diseases; diagnosis is performed by surgical biopsy of pulmonary nodules, using radiography. PCR diagnosis of dirofilariasis is sporadically used in Russia [89]. There are also absent any commercial IFA tests for Dirofilaria diagnostic in humans, however non-commercial immunoassay tests have been performed in some studies $[8,120]$.

\section{Treatment}

\section{Canine drofilariasis treatment}

Dirofilariasis treatment for dogs is based on clinical signs, the intensity of infection and data on laboratory tests (blood and urine analyses, ultrasonography, echocardiography) [1]. There are two methods of dirofilariasis treatment: macrofilaria therapy, and microfilaria therapy. Macrofilaria therapy is a complex treatment, which has high risk of side effects, due to massive destruction of adult worms in the bloodstream. Melasormine hydrochloride is used for macrofilaria treatment worldwide, according to standard protocol. To prevent anaphylactic shock due to adult helminths deaths, the antihistamine Tavegilum is administered to dogs at a dose of $0.05 \mathrm{mg} / \mathrm{kg}$ twice per day for five days after the beginning of treatment [124].

Supportive therapy includes immunomodulators (Ribotan, Ronkoleykin), hepatoprotectors (Karsil, Essenciale), analeptics (Sulphocamphokain), drugs improving blood microcirculation (Trental), drugs influencing metabolic processing in cardio musculature (Riboxin, Cocarboxylase), infusion solutions (salt and colloid solutions). Supportive therapy is provided based on clinical signs after evaluation of the individual situation for each animal. Restriction of physical activity is also used for avoiding the risk of pulmonary thromboembolism. For microfilaria therapy, macrocyclic lactones (avermectins, milbemycins, ivermictin (ivomec) are frequently used. Angiotensin-converting-enzyme (ACE) inhibitors are also used in supportive therapy for reducing renal vascular resistance. To exclude the possibility of an anaphylactic reaction due to high microfilaremia, therapy is combined with antihistamine drugs (tavegil, diphenhydramine, suprastin, among others) [124, 125].

Surgical extraction of filaria from subcutaneous nodules is used for treatment of canine dirofilariasis. Recently, surgical therapy has also been performed on dogs with vena cava syndrome [1] using flexible alligator forceps introduced via the jugular vein [126].

\section{Human dirofilariasis treatment}

Antihelminthic therapy is not usually recommended for human dirofilariasis treatment. The surgery is used in most cases because worm extraction from subcutaneous nodules is a simple procedure [105]. However, treatment of pulmonary dirofilariasis is complex procedure, which included extraction of filaria from nodules in the pleura and lungs using videothoracoscopy and chemotherapy using Albendazole [112]. One case of human microfilaremia was successfully treated with Doxycycline, Albendazole and Diethylcarbamazine [127].

\section{Control and prevention}

Recently, dirofilariasis was included in Russian Sanitary Regulations and Standards (No.3.2.1333-03) in the category of "Rare helminthiasis». The current Russian Sanitary Regulations and Standard No.3.2.3215-14 regulates the order of organisation 
of preventive measures for dirofilariasis. The prevention of human and animal infestations is based on the interruption of vectorborne transmission of infestation: the extermination of mosquitoes, identification and treatment of domestic dogs and cats infected with Dirofilaria spp., the prevention of mosquito contact with domestic animals and man, regular monitoring of phenology, ecology of mosquitoes that potentially transmit Dirofilaria spp. [128]. In addition, complex measures against larvae of mosquitoes in ponds or houses using insecticide are regularly provided in centres of Dirofilaria infection. Yearly monitoring of Dirofilaria spp. infestation rates in domestic dogs and cats are conducted in spring-summer time. Chemoprophylaxis is provided for dogs that reside in regions where canine dirofilariasis is endemic [86].

\section{Xenomonitoring}

Average xenomonitoring is provided by entomologists [129].

Entomological monitoring of vector species, including mosquito collection, determination of species, evaluation of population distribution, evaluation of seasonal and daily population dynamics, epidemiological importance of individual species, definition of hatching larvae spaces and concentration of imago [129].

Investigation of Dirofilaria spp. prevalence in mosquitoes is based on microscopy and molecular diagnostics methods. For evaluation of the epidemiological situation of controlled timing of the epidemic season of dirofilariasis in territories of the high prevalence (start and end dates of seasons with infected mosquitoes and effective transmission of dirofilariasis) and determination of the number of generations of larvae of Dirofilaria-carrying mosquitoes are calculated.

The transmission period of Dirofilaria spp. is calculated based on average temperature data. Calculation begins from the day when the established daily average temperature is $14^{\circ} \mathrm{C}$ ( 0 units of Dirofilaria development (HDU, heartworm development units)), and at a temperature exceeding the threshold $\left(14^{\circ} \mathrm{C}\right), \mathrm{HDU}$ are accumulated. The season of infected mosquitoes began when HDU was 130 . Other parameters such as the period of $L 3$ development in mosquito species and the total number of Dirofilaria spp. larva generation $(\mathrm{N})$ are also calculated [129].

Measures of mosquito population control include entomological and sanitary surveys, realisation of prevention works, and destroying of mosquito larvae [129].

\section{Pet infestation prevention measures}

According to high morbidity among infected animals and difficulty of dirofilariasis therapy, prophylactic and preventive measures are very important. Complex preventive procedures include:

i) Yearly monitoring of microfilaria in the blood of domestic cats and dogs, with the total number of investigated animals being at least 200 specimens in a Federal District.

ii) Microfilaria therapy of affected animals.

iii) Veterinarian practitioners and epizootologists provide explanatory works for heartworm disease prevention measures with pet owners. iv) Monthly chemoprophylactic with Dironet starts one month prior to the transmission period and finishes one month after this period ends.

v) In the spring Summer period it is highly recommended to use repellents for protecting dogs against mosquitoes.

vi) It is necessary to conduct further training for heartworm disease diagnosis and treatment of veterinarian practitioners especially in interdistrict clinics and laboratories $[130,131]$.

\section{Dirofilariasis prognosis}

Latest published studies of the epidemiological situation of dirofilariasis in Russian Federation have shown an unfavourable outlook [132]. Data for dirofilariasis in the Russian Federation are incomplete and randomly published. Due to this the absence of adequate forms of dirofilariasis reports, which was introduced only in 2013, it is difficult to estimate a clear epidemiological situation. Reports of canine dirofilariasis have been published from 17 regions, whereas human dirofilariasis have been registered in 42 regions [132]. Moreover, most surveys were conducted using only blood sample microscopy, so the prevalence of each Dirofilaria species was not estimated [56, 60-62, 72]. High sensitivity methods, such as immunoassay tests (gold standard for dirofilariasis diagnosis) and PCR, are available for only a few large veterinary centres [119-121]. Clinical epidemiology and treatment of canine dirofilariasis are considerable, but not thoroughly studied [73, 74]. The role of wild carnivorous mammals is also underestimated. Studies of obligate mutualistic endosymbiont bacteria Wolbachia identification and influence of dirofilariasis pathogenicity in animal and humans are not provided in Russia, whereas detection of Wolbachia antigens is a major tool for Dirofilaria infection diagnostic $[133,134]$. More studies about the transmission of both Dirofilaria species by mosquito vectors are clearly needed. Although monthly chemoprophylactic in dogs was successful at reducing Dirofilaria spp. infestation among dogs, prophylactic and preventive procedures are not provided in all regions where dirofilariasis is found. Control programmes are mainly implemented in zones with high and stable risks of infection, whereas zones with low risk of infestation rarely have control procedures. In addition, there are no published reports that help to estimate results of control and prevention programmes. Inadequate diagnosis and treatment in rural areas and towns also contributes to high levels of dirofilariasis.

\section{Conclusion}

This review shows the difficult epidemiological situation of dirofilariasis in Russia. Preventive procedures are major importance for decreasing of Dirofilaria infection rates in dogs and humans. The success of control and prevention programmes was only evident when all aspects and steps of procedures were thoroughly performed for a considerable number of years. Regular monitoring of dirofilariasis infestation cases among domestic pets, humans and wild carnivorous mammals help to create an epidemiological map of dirofilariasis in Russia, and helps to evaluate the effect of the control programmes. It is necessary to support programmes of public health education, modernisation of veterinary clinics, especially in rural areas, regular training of veterinarian practitioners, epidemiologists, medical employers and public health workers with diagnosis, treatment and prophylactic 
of dirofilariasis skills. All these gaps present obstacles to the effective integration of the knowledge of dirofilariasis in Russia.

\section{Acknowledgments}

This research received no specific grant from any funding agency in the public, commercial, or not-for-profit sectors.

Conflict of interest: none declared.

\section{References}

1. Simón F, Siles-Lucas M, Morchón R, González-Miguel J, Mellado I, Carretón E, Montoya-Alonso JA. Human and animal dirofilariasis: the emergence of a zoonotic mosaic. Clin Microbiol Rev 2012; 25(3): 507544. https://dx.doi.org/10.1128/CMR.00012-12.

2. Sałamatin R, Pavlikovska T, Sagach O, Nikolayenko S, Kornyushin V, Kharchenko $V$, et al. Human dirofilariasis due to Dirofilaria repens in Ukraine, an emergent zoonosis: epidemiological report of 1465 cases. Acta Parasit 2013; 58(4): 592-598. https://doi.org/10.2478/s11686013-0187-x.

3. Levine SE, Mossler JA, Woodard BH. Dirofilaria immitis: a zoonosis of clinical concern. South Med J 1980;73(6): 749-750. https://www.ncbi.nlm.nih.gov/pubmed/7190328.

4. Darchenkova NN, Supryaga VG, Guzeeva MV, Morozov EN, Zhukova LA, Sergiev VP. Prevalence of human dirofilariasis in Russia. Med Parasitol Parasit Dis 2009; 2: 3-7. Russian. http://www.ncbi.nlm.nih.gov/pubmed/19569266.

5. Otto GF. Geographical distribution, vectors, and life cycle of Dirofilaria immitis. J Am Vet Med Assoc 1969; 154(4): 370-373. https://www.ncbi.nlm.nih.gov/pubmed/4387985.

6. Bray RL, Walton $B C$. The life cycle of Dirofilaria uniformis Price and transmission to wild and laboratory rabbits. J Parasitol 1961; 47(1): 1322. https://dx.doi.org/10.2307/3274966.

7. Aspock H. Dirofilaria and dirofilarioses. Introductory remarks. In: Helminthologische Fachgesprächehelminthological Colloquium. H. Auer, C. Hörweg, H. Prosl, H. Sattmann, eds. Proceedings of Helminthological Colloquium. Vienna, 2003

8. Ermakova, LA, Nagorny SA, Krivorotova EY, Pshenichnaya NY, Matina ON. Dirofilaria repens in the Russian Federation: current epidemiology, diagnosis, and treatment from a federal reference center perspective. Int J Infect Dis 2014; 23: 47-52. https://dx.doi.org/10.1016/j.ijid.2014.02.008.

9. Ilyasov B, Kartashev V, Bastrikov N, Madjugina L, González-Miguel J, Morchón R, Simón F. Thirty cases of human subcutaneous dirofilariasis reported in Rostov-on-Don (Southwestern Russian Federation). Enferm Infecc Microbiol Clin 2015; 33(4): 233-237. https://dx.doi.org/10.1016/i.eimc.2014.04.002.

10. Hoch $H$, Strickland $K$. Canine and feline dirofilariasis: life cycle, pathophysiology, and diagnosis. Compend Contin Educ Vet 2008; 30(3): 133-140. https://www.ncbi.nlm.nih.gov/pubmed/18409140.

11. Genchi C, Genchi M, Petry G, Kruedewagen EM, Schaper R. Evaluation of the efficacy of imidacloprid $10 \%$ /moxidectin $2.5 \%$ (Advocate ${ }^{\circledR}$, Advantage ${ }^{\circledR}$ Multi, Bayer) for the prevention of Dirofilaria repens infection in dogs. Parasitol Res 2013; 112(Suppl 1): 81-89. https://dx.doi.org/10.1007/s00436-013-3283-9.

12. Milanez de Campos JR, Barbas CS, Filomeno LT, Fernandez A, Minamoto $\mathrm{H}$, et al. Human pulmonary dirofilariasis: analysis of 24 cases from Sao Paulo, Brazil. Chest 1997; 112(3): 729-733. https://doi.org/10.1378/chest.112.3.729.

13. Fuehrer HP, Auer H, Leschnik M, Silbermayr K, Duscher G, Joachim A. Dirofilaria in humans, dogs, and vectors in Austria (1978-2014)-From imported pathogens to the endemicity of Dirofilaria repens. PLoS Negl $\begin{array}{llll}\text { Trop Dis 2016; 10(5): } & \text { e0004547. }\end{array}$ https://dx.doi.org/10.1371/journal.pntd.0004547.
14. Damle AS, Iravane JA, Khaparkhuntikar MN, Maher GT, Patil RV. Microfilaria in human subcutaneous dirofilariasis: a case report. J Clin Diagn Res 2014; 8(3): 113-114. https://dx.doi.org/10.7860/JCDR/2013/6886.4123.

15. Genchi C, Rinaldi L, Mortarino M, Genchi M, Cringoli G. Climate and Dirofilaria infection in Europe. Vet Parasitol 2009; 163(4): 286-292. https://dx.doi.org/10.1016/i.vetpar.2009.03.026.

16. Kotani T, Powers KG. Developmental stages of Dirofilaria immitis in the dog. Am J Vet Res 1982, 43(12): 2199-2206. https://www.ncbi.nlm.nih.gov/pubmed/7165165.

17. Tarello W. Clinical aspects of dermatitis associated with Dirofilaria repens in pets: a review of 100 canine and 31 feline cases (1990-2010) and a report of a new clinic case imported from Italy to Dubai. J Parasitol Res 2011; 2011: 578385. https://dx.doi.org/10.1155/2011/578385.

18. Rocconi F, Di Tommaso M, Traversa D, Palmieri C, Pampurini F, Boari A. Allergic dermatitis by Dirofilaria repens in a dog: clinical picture and treatment. Parasitol Res 2012; 111(1): 493-496. https://dx.doi.org/10.1007/s00436-012-2833-x.

19. Kamalu BP. Canine filariasis caused by Dirofilaria repens in southeastern Nigeria. Vet Parasitol 1991; 40(3-4): 335-338. https://www.ncbi.nlm.nih.gov/pubmed/1788940.

20. Bredal WP, Gjerde B, Eberhard ML, Aleksandersen M, Wilhelmsen DK, Mansfield LS. Adult Dirofilaria repens in a sub-cutaneous granuloma on the chest of a dog. J Sm Anim Pract 1998; 39(12): 595-597. https://www.ncbi.nlm.nih.gov/pubmed/9888115.

21. Flieder DB, Moran CA. Pulmonary dirofilariasis: a clinicopathologic study of 41 lesions in 39 patients. Hum Pathol 1999; 30(3): 251-256. https://www.ncbi.nlm.nih.gov/pubmed/10088541.

22. Polizopoulou ZS, Koutinas AF, Saridomichelakis MN, Patsikas MN, Leontidis LS, Roubies NA, Desiris AK. Clinical and laboratory observations in 91 dogs infected with Dirofilaria immitis in northern Greece. Vet Rec 2000; 146(16): 466-469. https://www.ncbi.nlm.nih.gov/pubmed/10819132.

23. González-Miguel J, Morchón R, Siles-Lucas M, Simón F. Fibrinolysis and proliferative endarteritis: two related processes in chronic infections? The model of the blood-borne pathogen Dirofilaria immitis. PloS One 2015; 10(4): e0124445. https://dx.doi.org/10.1371/journal.pone.0124445.

24. Bowman DD, Liu Y, McMahan CS, Nordone SK, Yabsley MJ, Lund RB. Forecasting United States heartworm Dirofilaria immitis prevalence in dogs. Parasite Vectors 2016; 9(1): 540. https://dx.doi.org/10.1186/s13071-016-1804-y.

25. Hirano $Y$, Kitagawa $H$, Sasaki $Y$. Relationship between pulmonary arterial pressure and pulmonary thromboembolism associated with dead worms in canine heartworm disease. J Vet Med Sci 1992; 54(5): 897-904. https://www.ncbi.nlm.nih.gov/pubmed/1420571.

26. Calvert CA, Losonsky JM. Pneumonitis associated with occult heartworm disease in dogs. J Am Vet Med Assoc 1985; 186(10): $1097-$ 1098. https://www.ncbi.nlm.nih.gov/pubmed/3997626.

27. Simón F, López-Belmonte J, Marcos-Atxutegi C, Morchón R, MartínPacho JR. What is happening outside North America regarding human dirofilariasis? Vet Parasitol 2005; 133(2): 181-189. https://dx.doi.org/10.1016/j.vetpar.2005.03.033.

28. Nath R, Gogoi R, Bordoloi N, Gogoi T. Ocular dirofilariasis. Indian J Pathol Microbiol 2010; 53(1): 157. https://dx.doi.org/10.4103/03774929.59213.

29. Asimacopoulos PJ, Katras A, Christie B. Pulmonary dirofilariasis: the largest single-hospital experience. Chest 1992; 102(3): 851-855. https://doi.org/10.1378/chest.102.3.851.

30. Pampiglione S, Schmid C, Montaperto C. Human dirofilariasis: discovery of a gravid female of Dirofilaria repens in a subcutaneous nodule. Pathologica 1991; 84(1089): 77-81. https://www.ncbi.nlm.nih.gov/pubmed/1495852. 
31. Vanhaecke C, Perignon A, Monsel G, Regnier S, Paris L, Caumes E. Aetiologies of creeping eruption: 78 cases. Br J Dermatol 2014; 170(5): 1166-1169. https://dx.doi.org/10.1111/bjd.12637.

32. Leccia N, Patouraux S, Carpentier X, Boissy C, Del Giudice P, Parks S, et al. Pseudo-tumor of the scrotum, a rare clinical presentation of dirofilariasis: a report of two autochthonous cases due to Dirofilaria repens. Pathog Glob Health 2012; 106(6): 370-372. https://dx.doi.org/10.1179/2047773212Y.0000000029.

33. Stayerman C, Szvalb S, Sazbon A. Dirofilaria repens presenting as a subcutaneous nodule in the penis. BJU Int 1999; 84: 746-747. https://www.ncbi.nlm.nih.gov/pubmed/10510134.

34. Patrikar A, Maimoon S, Mahore S. Filarial granuloma in breast. Indian J Pathol 2008; 51(1): 85. https://www.ncbi.nlm.nih.gov/pubmed/7325279.

35. Friedman PD, Kalisher L. Case 43: Filariasis 1. Radiology 2002; 222: 515-517. https://doi.org/10.1148/radiol.2222991841.

36. Ng WK, Siu TH, Fung B, Kong JH. Dirofilariasis of breast: Report of two cases diagnosed by fine-needle aspiration biopsy. Diagn Cytopathol 2002; 26(1): 22-25. https://www.ncbi.nlm.nih.gov/pubmed/11782082.

37. Zweig A, Karasik A, Hiss J. Dirofilaria in a cervical lymph node in Israel. Hum Pathol 1981; 12(10): 939-940. https://www.ncbi.nlm.nih.gov/pubmed/7298051.

38. De Gentile L, Cerez H, François H, Ronceray J, Chabasse D. Peritoneal dirofilariasis fortuitously disclosed. Bull Soc Pathol Exot 1992; 85(2): 171-173. French. https://www.ncbi.nlm.nih.gov/pubmed/1327358.

39. Font RL, Neafie RC, Perry HD. Subcutaneous Dirofilariasis of the Eyelid and Ocular Adnexa: Report of six cases. Arch Ophthalmol 1980; 98(6): 1079-1082. https://www.ncbi.nlm.nih.gov/pubmed/7387513.

40. Bhat KS, Kotigadde S, Bhat KV, Pare P.. Subconjunctival dirofilariasis: Case studies with review of literature. Trop Parasitol 2014; 4(2): 119121. https://dx.doi.org/10.4103/2229-5070.138541.

41. Sathyan P, Manikandan P, Bhaskar M, Padma S, Singh G, Appalaraju B. Subtenons infection by Dirofilaria repens. Indian J Med Microbiol 2006; 24(1): 61-62. https://dx.doi.org/10.4103/0255-0857.19899.

42. Gupta V, Sankaran P, Samantaray J, Menon V. Bilateral intraocular dirofilariasis. Indian J Ophthalmol 2014; 62(3): 357-358. https://dx.doi.org/10.4103/0301-4738.116252.

43. de Campos JRM, Barbas CSV, Filomeno LTB, Fernandez A, Minamoto $H$, Barbas Filho JV, Jatene FB. Human pulmonary dirofilariasis: analysis of 24 cases from Sao Paulo, Brazil. Chest 1997; 112(3): 729-733. https://doi.org/10.1378/chest.112.3.729.

44. Flieder DB, Moran CA. Pulmonary dirofilariasis: a clinicopathologic study of 41 lesions in 39 patients. Hum Pathol 1999; 30(3): 251-256. https://www.ncbi.nlm.nih.gov/pubmed/10088541.

45. Katikireddy CK, Kuschner WG. Pulmonary Dirofilariasis presenting as multiple pulmonary nodules in a patient with a history of lymphoma. Chest 2005; 128(4): 481S-482S. https://dx.doi.org/10.1378/chest.128.4_MeetingAbstracts.481S.

46. Genchi C, Mortarino M, Rinaldi L, Cringoli G, Traldi, G, Genchi M. Changing climate and changing vector-borne disease distribution: the example of Dirofilaria in Europe. Vet Parasitol 2011;176: 295-299. https://doi.org/10.1016/j.vetpar.2011.01.012.

47. Huldén L, Hulden L. Checklist of the family Culicidae (Diptera) in $\begin{array}{llll}\text { Finland. Zookeys 2014; 441: } & \end{array}$ https://doi.org/10.3897/zookeys.441.7743.

48. Gornostaeva RM. A catalog of mosquito species (Culicidae family) from the Asian region of Russia. Parasitologiia 2000; 34: 477-485. Russian. https://www.ncbi.nlm.nih.gov/pubmed/11212615.

49. Gornostaeva RM. A checklist of the mosquitoes (fam. Culicidae) in the European part of Russia. Parazitologiia 2000; 34(5): 428-434. Russian. https://www.ncbi.nlm.nih.gov/pubmed/11089252.

50. Bezzhonova OV, Patraman IV, Ganushkina LA, Vyshemirsky OI, Sergiev VP. The first finding of invasive species Aedes (Finlaya) koreicus (Edwards, 1917) in European Russia. Med Parazitol (Mosk) 2014; (1): 16-19. Russian. https://www.ncbi.nlm.nih.gov/pubmed/24738221.
51. Petrov YuF, Kryuchkova YN, Trusova AV, Korenskova YV, Shinkarenko AN. Circulation of heteroxenous helminthes in carnivorous of European part of the Russian Federation. Russian Journal of Parasitology 2011; 3: 59-61. Russian. https://elibrary.ru/item.asp?id=17239864.

52. Rakova VM, Uspensky AV, Arhipov IA, Kurochkin KG, Novick TS, Koveshnikova EL, Yershov TA. Molecular studies of Dirofilaria immitis and Dirofilaria repens using the direct PCR method in mosquitoes in Moscow and Nizhny Novgorod Provinces. Teorija i Praktika Parazitarnyh Boleznej Zhivotnyh 2013; 14: 308-310. Russian. https://www.cabdirect.org/cabdirect/abstract/20143277662.

53. Petrov YuF, Egorov SV. The ecology of Culicidae and Simuliidae - a vectors of parasitic diseases of animals in the Central region of NonBlack soil zones of Russian Federation. Russian Journal of Parasitology 2011; 4: 52-4. Russian. https://elibrary.ru/item.asp?id=17239888.

54. Bogacheva AS,Ganushkina LA,Lopatina YV. Infection of blood-sucking mosquitoes (Diptera: Culicidae) with Dirofilariae (Spirurida, Onchocercidae) in the Tula Region. Med Parazitol (Mosk) 2016; (2): 812. Russian. https://www.ncbi.nlm.nih.gov/pubmed/27405207.

55. 55. Bartkova AD, Poliakova LF, Ermolenko AV. Human dirofilariasis in the Primorye Territory. Med Parazitol (Mosk) 2011; (1): 47-48. https://www.ncbi.nlm.nih.gov/pubmed/21480556.

56. 56. Ivanova IB,. Ganushkina LA. Analysis of microfilarial infection of bloodsucking mosquitoes (Family Culidae) caught on the territory of Khabarovsk City. Far Eastern Journal of Infectious Pathology 2013; 23: 51-57. Russian. https://elibrary.ru/item.asp?id=21486176.

57. Krivorotova EYu, Nagorny SA. Dirofilaria spp. infections in the health resort city of Anapa. Theory and Practice of Struggle Against Parasitic Diseases 2011; 12: 253-254. Russian. https://cyberleninka.ru/article/n/dirofilyarioz-v-gorode-kurorte-anapa.

58. Krivorotiva EYu, Nagorny SA, Hutoryanina IV. Xenomonitoring of Dirofilaria spp. infection in the Rostov region. Theory and Practice of Struggle Against Parasitic Diseases 2016; 17: 210-213. Russian. https://cyberleninka.ru/article/n/ksenomonitoring-dirofilyarioza-vrostovskoy-oblasti.

59. Krivorotova EY, Nagorny SA. Dirofilyarioz's mapping the person in the Russian Federation. International Journal of Applied and Fundamental Research 2016; 1: 187-190. Russian. https://elibrary.ru/item.asp?id=25372552.

60. Artamonova A. Cases of dirofilariasis in the Rostov Region in Helminthiasis in Humans. Russia, St-Petersburg: VMedA, 1989. Russian.

61. Nagorny SA, Krivorotova EYu, Rosolovsky AP, Pyanich VA, Ignatyeva VI, Matina ON, Emelyanova ON, Shevchuk EA. Dirofilaria spp. infection rates in dogs in the Novgorod Region. Theory and Practice of Struggle Against Parasitic Diseases 2013; 14: 258-260. Russian. https://elibrary.ru/item.asp?id=30461669.

62. Mezentsev SV. Epizootology of dirofilariasis in dogs in the Altai region. Vestnik Altaiskogo Gosudarstvennogo Agrarnogo Universiteta 2013; 5: 110-13. Russian. https://elibrary.ru/item.asp?id=19012046.

63. Yastreb VB. Epizootic situation on dirofilariosis of dogs in Moscow region. Russian Journal of Parasitology 2008; (3): 63-68. Russian. https://elibrary.ru/item.asp?id=11769539.

64. Maslennikova OV, Perletckaya OV. Recovery of Dirofilaria repens (Raillet et Henri, 1911) in a dog in the Kirov Region. Theory and Practice of Struggle Against Parasitic Diseases 2012; 13: 243-244. Russian. https://elibrary.ru/item.asp?id=30311058.

65. Zolotykh TA, Bespalova NS. Dirofilariasis in dogs in Voronezh and Voronezh region. Russian Journal of Parasitology 2015; (2): 38-42. Russian. https://elibrary.ru/item.asp?id=23855298.

66. Kravchenko IA, Gnenenko AA. Dynamics of distribution of droophilariosis of dogs and cats in Barnaul. Vestnik Altaiskogo Gosudarstvennogo Agrarnogo Universiteta 2007; (6): 42-45. Russian. https://elibrary.ru/item.asp?id=12516192.

67. Vinokurova DP. Spreading and pathomorphology of dirofilariasis in dogs and cats in Krasnodar Region. Abstract of PhD thesis. 
Stavropol, Russia, 2011; 20 p. Russian. http://stgau.ru/science/dis/avtoreferat/vinokurova.pdf.

68. Ivanova IB. Significance of dirofilariosis in the city of Khabarovsk. Distribution and diagnostics. Dal'nevostochnyj Zhurnal Infekcionnoj Patologii 2010; 17: 204-208. Russian. https://elibrary.ru/item.asp?id=18379622.

69. Kolesova GG, Reshetnikov AD, Sleptsov ES, Barashkova Al. Dirofilariosis of carnivorous in Yakutia, the method of isolation filarial larvae from the blood of dogs. Russian Journal of Parasitology 2013; (3): 87-91. Russian. https://elibrary.ru/item.asp?id=20407240.

70. Sogrina AV. Situation of dirofilariasis in service and hunter's dogs in Perm region on 2015. Transactions of Center for Parasitology 2016; 49: 169-171. Russian.

71. Arkhipov IA, Arkhipova DR. Dirofilariasis. Moscow, Russia, 2004. Russian.

72. Koroleva SN, Kondratieva UA. Invasion extensiveness in war dogs of the Kostroma region. Voprosy Normativno-Pravovogo Regulirovanija $v$ Veterinarii 2012; (4): 29-31. Russian. https://elibrary.ru/item.asp?id=22652533.

73. Kravchenko VM, Frolov AM. Patogeneza dirofilyarioz's some aspects of the house and wild carnivorous. Uchenye Zapiski Kazanskoj Gosudarstvennoj Akademii Veterinarnoj Mediciny im. N.Je. Baumana 2013; 214: 225-228. Russian. https://elibrary.ru/item.asp?id=19018417.

74. Yastreb VB. Clinical signs of dirofilariosis of dogs caused by Dirofilaria immitisand D. repens. Russian Journal of Parasitology 2009; (2): 86-91. Russian. https://elibrary.ru/item.asp?id=12874694.

75. Kolesnikov PV. Comparative aspects of electrocardiographic parameters in some parasitic diseases in dogs. Izvestija Nizhnevolzhskogo Agrouniversitetskogo Kompleksa: Nauka i Vysshee Professional'noe Obrazovanie 2014; (3): 127-131. Russian. https://elibrary.ru/item.asp?id=17954632.

76. Skrjabin KI, Al'tgauzen AY, Shul'man ES. The first case of dirofilariasis in human. Tropicheskaya Meditsina i Veterinariya 1930; (7): 9-11. Russian.

77. Ivanova IB, Trotsenko OE, Karavianskaia TN, Ganushkina LA. Human dirofilariasis in the city of Khabarovsk. Med Parazitol (Mosk) 2013; (3): 18-20. Russian. https://www.ncbi.nlm.nih.gov/pubmed/25924277.

78. Epshtein Shl, Lychmanov NG. Case of Dirofilaria infection in man. Med Parazitol (Mosk) 1954; (2): 175-176. Russian. https://www.ncbi.nlm.nih.gov/pubmed/13175912.

79. Azarova NA, Cherkashina EN, Grishina NL, Ivleva EP. Dirofilariasis in the Altai edge. Infektsiya i Immunitet 2012; 2: 351. Russian.

80. Dirofilariasis in Penzenskii District in 2013 year. Accessed 4 Feb 2017. Russian. http://58.rospotrebnadzor.ru/rss_all/Lasset_publisher/Kq6J/content/id/290168.

81. Gubernatorova VV, Mukatdisova ZG. Dirofilariasis of man in the Ivanovo province. Bulletin of the Ivanovo Medical Academy 2012; 17(3): 59-60. Russian. https://elibrary.ru/item.asp?id=18085698.

82. About intensification of preventive measure of parasitic diseases in Perm Region. Accessed 4 Feb 2017. Russian. http://59.rospotrebnadzor.ru/c/document library/get file?uuid=9a42 c58a-29a6-420d-ae56-03fe6efb5cd5\&groupld=10156.

83. Kiryushenkova VV, Labuzov DS, Tarasov AA, Haikova OM. Case of dirofilariasis in the Smolensk Region. Vestnik Smolenskoj Gosudarstvennoj Medicinskoj Akademii 2014; 13(2): 77-79. Russian. https://elibrary.ru/item.asp?id=22470355.

84. Byakova OV, Maslennikova OV, Ermolina SA. Dirofilariosis - new zoonotic disease in Kirov Region. Vjatskij Medicinskij Vestnik 2014; (1): 19-21. Russian. https://elibrary.ru/item.asp?id=22105720.

85. Kocherov AA, Lobanov AV, Chuprynin AV. Case of acute orchiepididymitis caused by helminth (Dirofilaria repens). Urologicheskie Vedomosti 2015; 5(1): 104-105. Russian. http://dx.doi.org/10.17816/uroved51104-105.
86. Moskalev VG, Ermilov IV. Dirofilariasis preventive procedures on territoty of Kursk Region. Vestnik Kurskoj Gosudarstvennoj Sel'skohozjajstvennoj Akademii 2015; (2): 58-59. Russian. https://elibrary.ru/item.asp?id=23293384.

87. Zotina GP, Tikhonova EP, Sergeeva IV, Kuzmina TYu, Andronova NV, Upirova AA. Cutaneous some helminthiasis. difficulties early diagnosis. Modern Problems of Science and Education 2015; (5): 172. Russian. https://elibrary.ru/item.asp?id=24848048.

88. Kartashev V, Batashova I, Kartashov S, Ermakov A, Mironova A, Kuleshova $\mathrm{Y}$, et al. Canine and human dirofilariosis in the Rostov region (southern Russia). Vet Med Int 2011; 2011: 685713. http://dx.doi.org/10.4061/2011/685713.

89. Kramer LH. Human Subcutaneous Dirofilariasis, Russia. Emerg Infect Dis 2007; 13(1): 150. https://dx.doi.org/10.3201/eid1301.060920.

90. Belova NE. Dirofilariasis in the Nizhny Novgorod Region. Med Parazitol (Mosk) 2012; (2): 18-20. Russian. https://www.ncbi.nlm.nih.gov/pubmed/22774500.

91. Kartashev V, Tverdokhlebova T, Korzan A, Vedenkov A, Simón L, González-Miguel J, et al. Human subcutaneous/ocular dirofilariasis in the Russian Federation and Belarus, 1997-2013. Int J Infect Dis 2015; 33: 209-211. https://dx.doi.org/10.1016/j.ijid.2015.02.017.

92. Arakelian RS, Galimzianov KhM, Arakelian AS. Dirofilariasis in Astrakhan region: this problem today. Aktual'naja Infektologija 2014; 4: 81-85. Russian. http://dx.doi.org/10.22141/2312413x.4.05.2014.82502.

93. Gus'kov VV, Gorshkova EV, Postnova VF, Agarunov AV. Dirofilariasis in Astrakhan Region. The problem of diagnostic and treatment. Lechashchiy Vrach 2001; (1): 55-57. Russian. https://www.lvrach.ru/2001/01/4528492.

94. Aleksandrovich EV, Vakhnenko AA, ZaitsevAS, Serga OA, Nedostupova EYu. Relevance of problem of dirofilariasis in the Amur Region. Vestnik Sovremennoj Klinicheskoj Mediciny 2012; (5): 74-76. Russian. https://dx.doi.org/10.20969/VSKM.2012.5(3).74-76.

95. Tihonova EP, Kuzmina TYU, Tihonova ES. The case of Dirofilariasis in Krasnoyarsk. Sibirskoe Medicinskoe Obozrenie 2010; 63: 99-101. Russian. https://elibrary.ru/item.asp?id=15126865.

96. Gavrilova TV, Chereshneva MV, Chetina EN,. Sobyanin NA. Rare cases of eye dirofilariasis in Perm city. Ophthalmosurgery 2012; (4): 86-87. Russian. https://elibrary.ru/item.asp?id=18903145.

97. Rosolovskii AP, P'ianykh VA, Ignat'eva VI, Matina ON, Shevchuk EA, Danilova EP, et al. Dirofilariasis in the Nizhny Novgorod Region. Med Parazitol (Mosk) 2013; 1: 34-35. Russian. https://www.ncbi.nlm.nih.gov/pubmed/23805487.

98. Tolkunova II,Ulacevich RA,lakovleva EG. Recording a case of dirofilariasis in residents of Novosibirsk. Med Parazitol (Mosk) 2003; (1): 26. Russian. https://www.ncbi.nlm.nih.gov/pubmed/12652844.

99. Hrjashheva NA, Ryabinina TL. Registration of dirofilariasis in Yaroslavskii Region. Infekcija i Immunitet 2012; 2: 388. Russian. https://cyberleninka.ru/article/n/registratsiya-sluchaev-dirofilyariozav-yaroslavskoy-oblasti.

100. Sharova TA. Ocular dirofilariasis in Vologodskii Region. Tochka Zrenija. Vostok-Zapad 2015; (1): 201-202. Russian. https://elibrary.ru/item.asp?id=24131024.

101. Budaev AP, Grebenik LA, Gromov AL, Moskalev VG. Clinical case of revealing dirofilaria repens in the man with localization in buccal area with the use of ultrasonic research. Kurskij Nauchno-Prakticheskij Vestnik "Chelovek i Ego Zdorov'e" 2014; (4): 46-48. Russian. https://elibrary.ru/item.asp?id=22841477.

102. Shlykov Al, Karavayev NS, Chugunova GN, Erkin IE. Cases dirofilariosis in polyclinic practice. Pavlov Russian Medical Biological Herald 2010; 18: 26-30. Russian. http://dx. doi.org/10.17816/PAVLOVJ2010226-30.

103. Zumbulidze NG, Kasimov FO, Yarovoy DA, Gavrilova EP. Ocular dirofilariasis: two case reports. Oftal'mologicheskie Vedomosti 2016; 9: 83-89. Russian. https://dx.doi.org/10.17816/OV9183-89. 
104. Kamynina EA. Dirofilariasis in Kurgan Region. Infektsiya i Immunitet 2012; 2: 363-364. Russian. https://cyberleninka.ru/article/n/dirofilyarioz-v-kurganskoy-oblasti.

105. Gainutdinova RF, Tukhbatullin MG, Gilmullina FS, Nefedov VP, Pigalova OM, Bikmuchametova DA. Diagnostics of human dirofilariasis. Prakticheskaja Medicina 2012; (1): 123-126. Russian. https://elibrary.ru/item.asp?id=17335443.

106. Grigor'eva MV, Dvorovenko EV. Dirofilariasis of testicular membranes under a mask of the syndrome of edematic and hyperemic scrotum. Vestnik Infektologii i Parazitologii 2003; (2): 15. Russian. http://www.infectology.ru/publik/stat37.aspx.

107. Streltsova OS, Krupin VN, Grebenkin EV, Mamonov MV, Osipov AA. Dirofilariasis of the penis. Herald Urology 2016; (1): 86-92. Russian. https://elibrary.ru/item.asp?id=27310107.

108. Laskin AV. Case of subcutaneous dirofilariasis in patient admitted to the surgical hospital of St. Petersburg. Infekcija i Immunitet 2012; (2): 369-370. Russian. https://cyberleninka.ru/article/n/sluchaypodkozhnogo-dirofilyarioza-u-bolnoy-postupivshey-v-hirurgicheskiystatsionar-sankt-peterburga.

109. Likhachev SA, Nedz'ved' MK, Astapenko AV, Elenskaja SV, Sidorovich RR, Brant EV, et al. Case of dirofilariasis of brain: clinic description. Nevrologicheskij Zhurnal 2013; (2): 42-47. Russian. https://elibrary.ru/item.asp?id=19040758.

110. Sosnin DY, Kozyukov VG, Kadyntsev IV, Taskaev AL, Shchekotova AP, Karimova NV, Galimova AA. Dirofilariasis of tendinous sheath of extensor pollicis longus imitating dorsal hand ganglion cysti a case report. Traumatology and Orthopedics of Russia 2016; 22: 117-121. Russian. https://dx.doi.org/10.21823/2311-2905-2016-22-3-117-121.

111. Supriaga VG, Tsybina TN, Denisova TN, Morozov EN, Romanenko NA, Starkova TV. The first case of diagnosis of dirofilariasis from the microfilariae detected in the human subcutaneous tumor punctate. Med Parazitol (Mosk) 2003; (4): 6-8. Russian. https://www.ncbi.nlm.nih.gov/pubmed/15689127.

112. Bronshtcyn A M, Malyshev NA, Jarov SN, Fedianina LV, Frolova AA, Davydova IV. Clinical masks of pleuropuhnonary dirofilariasis, a rare clinical presentation of dirofilariasis in Russia: a report of four cases and literature review. Epidemiology and Infectious Diseases 2015; 20(1): 43-49. Russian. https://elibrary.ru/item.asp?id=23464036.

113. Vjaz'menova NI, Chizhova TN, Kirgincev AG, Tjunikov BA, Avdjuhina TI, Markova OB, Komarova El. Pleural effusion with rare etiology. Prakticheskaja Pul'monologija 2008; (2): 63-65. Russian. https://elibrary.ru/item.asp?id=15176711.

114. Bronshtein AM, Malyshev NA, Luchshev VI, Supryaga VG, Mezhgikhova RM, Samsonova SE. Pleuropulmonary dirofilariasis with exudative pleurisy and erythema nodosum. Russian Medical Journal 2011; (1): 51-53. Russian. https://elibrary.ru/item.asp?id=15615190.

115. Bronshtein AM, Malyshev NA, Luchshev VI, FedyaninLV, Frolova AA, Supryaga VG. The first autochthonic case of pulmonary dirofilariasis in Russia. Epidemiology and Infectious Diseases 2011; (3): 50-53. Russian. https://elibrary.ru/item.asp?id=16499414.

116. Suprjaga VG, Andreenkov AI. Diagnosis of filariasis in persons with a low density of microfilaria in the blood. Med Parazitol (Mosk) 1978; 6: 100-2. Russian. https://www.ncbi.nlm.nih.gov/pubmed/364287.

117. Yastreb VB. Vital diagnosis of Dirofilaria spp. infection. Theory and Practice of Struggle Against Parasitic Diseases 2011; 12: 587-591. Russian. https://elibrary.ru/item.asp?id=24258822.

118. Arkhipova DR, Arkhipov IA. Quantitative method for dirofilaria detection in dogs. Tr Vser In-ta Gel'mintol 2004; 40: 18-22. Russian.

119. Favia G, Lanfrancotti A, Della Torre A, Cancrini G, Coluzzi M. Polymerase chain reaction-identification of Dirofilaria rerpens and Dirofilaria immitis. Parasitology 1996; 113(6): 567-571. https://www.ncbi.nlm.nih.gov/pubmed/8939053.

120. Beskrovnaya YuG, Nagorny SA, Vaserin Yul. Efficacy evaluation of diagnosis of Dirofilaria repens infection in humans using the $D$. repens somatic antigen. Theory and Practice of Struggle Against Parasitic
Diseases 2009; 10: 58-61. Russian.

https://cyberleninka.ru/article/n/otsenka-effektivnosti-diagnostikidirofilyarioza-cheloveka-s-ispolzovaniem-somaticheskogo-antigenadirofilaria-repens.

121. Beskrovnaya YuG, Nagorny SA, Vaserin Yul. Efficacy evaluation of diagnosis of Dirofilaria repens infection in dogs using the D. repens somatic antigen. Teorija i Praktika Parazitarnyh Boleznej Zhivotnyh 2009; 10: 61-64. Russian. https://cyberleninka.ru/article/n/otsenkaeffektivnosti-diagnostiki-dirofilyarioza-u-sobak-s-ispolzovaniemsomaticheskogo-antigena-dirofilaria-repens.

122. Khaydarov KA, Napisanova LA, Berezhko VK. Laboratory rules for identification in serum antibodies heartworm antigen from Setaria spp. Russian Journal of Parasitology 2009; 4: 126-128. Russian. https://elibrary.ru/item.asp?id=13076233.

123. Krivorotova EYu, Nagorny SA, Aleshukina AV, Korshunov SO. Matrixassisted laser desorption ionization mass spectrometry (MALDI-TOF MS) is the tool for specific identification of Dirofilaria repens and D. immitis. Theory and Practice of Struggle Against Parasitic Diseases 2014; 15: 119-122. Russian. https://elibrary.ru/item.asp?id=22676416.

124. Yastreb VB, Arkhipov IA. Recommendation on diagnostics, treatment and prophylactics of dirofilariosis of dogs in Moscow region. Russian Journal of Parasitology 2008; (4): 109-114. Russian. https://elibrary.ru/item.asp?id=11769569.

125. Kolodij IV, Ermakov AM, Bojko VP. Pathogenetic substantiation of correction of the common complications of therapy heartworm in dogs. Veterinarnaja Patologija 2012; (1): 83-86. Russian. https://elibrary.ru/item.asp?id=17761761.

126. Lapshin M, Kuznetcov P, Karpov K. Clinical case dirofilariosis the dog. Technique of surgical treatment. Vet Pharma 2014; (5): 81-85. Russian. https://elibrary.ru/item.asp?id=22442170.

127. Bronshteyn AM, Malyshev NA, Jarov SN, Fedianina LV, Frolova AA, Supriaga VG, Luchshev VI. A first autochtnous human case of the longstandindg microfilaraemia due to Dirofilaria repens in Russia and a first experience of combined therapy of Dirofilariasis repens. Epidemiologiya i Infektsionnye Bolezni 2013; 35: 47-52. Russian. https://elibrary.ru/item.asp?id=19694098.

128. Doronin-Dorgelinskiy EA. Legal basis of the organization of the fight against dirofilariasis in the russian federation. Permskij Agrarnyj Vestnik 2016; (2): 129-133. Russian. https://elibrary.ru/item.asp?id=28124631.

129. Krivorotova EY, Nagorny SA. Recomendations for specialists in entomological supervision and dirofilyarioz's ksenommonitoring. International Journal of Applied and Fundamental Research 2016; (12): 191-195. Russian. https://elibrary.ru/item.asp?id=25372553.

130. Postnova VF, Arakeljan RS, Galimzyanov HM, Shendo GL, Postnov AB, Ryabinkina MA. The most important trends of prophylaxis of Dirofilaria repens infection in humans. Teorija i Praktika Parazitarnyh Boleznej Zhivotnyh 2011; 12: 399-401. Russian. https://cyberleninka.ru/article/n/vazhneyshee-napravlenieprofilaktiki-dirofilyarioza-u-lyudey.

131. Dachno Yul, Dachno IS. Effects of bromovermectin-granulate against microfilaria aimed on prophylaxis and chemoprophylaxis of Dirofilaria infection in dogs. Theory and Practice of Struggle Against Parasitic Diseases 2013; 14: 127-129. Russian. https://elibrary.ru/item.asp?id=30461622.

132. Sergiev VP, Supriaga VG, Bronshteĭn AM, Ganushkina LA, Rakova VM, Morozov EN, et al. Results of studies of human dirofilariasis in Russia. Med Parazitol (Mosk) 2014; (3): 3-9. Russian. https://www.ncbi.nlm.nih.gov/pubmed/25286541.

133. Kramer L, Grandi G, Leoni M, Passeri B, McCall J, Genchi C, et al. Wolbachia and its influence on the pathology and immunology of Dirofilaria immitis infection. Vet Parasitol 2008; 158(3): 191-195. https://doi.org/10.1016/j.vetpar.2008.09.014.

134. Kozek WJ. What is new in the Wolbachia/Dirofilaria interaction? Vet Parasitol 2005; 133(2): https://doi.org/10.1016/j.vetpar.2005.02.005. 
Authors:

Tatyana V. Moskvina - PhD student, School of Natural Sciences, Far Eastern Federal University, Vladivostok, Russia. http://orcid.org/00000002-9517-7495.

Alexey V. Ermolenko - PhD, Senior scientist, Laboratory of Parasitology, Federal Sciencific Center of Terrestrial Biodiversity of Eastern Asia, Far Eastern Branch Russian Academy of Sciences, Vladivostok, Russia. https://orcid.org/0000-0002-6316-7831. 